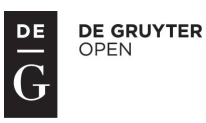

\title{
The Relationship betWeen Property Rights AND ECONOMIC GROWTH: AN ANALYSIS OF OECD AND EU COUNTRIES
}

\author{
Ceyhun Haydaroğlu ${ }^{1}$
}

\begin{abstract}
In recent years, institutions and institutional structure have become some of the most popular concepts analyzed by economics theory. New growth theories have especially focused on the effects of institutions and institutional structure on a macro level. Property rights are one of the most important elements of this institutional structure. The relationship between property rights and economic growth have drawn the attention of many researchers and policymakers in recent years. The aim of this study, covering the period 2007-2014, is to examine the relationship between property rights and economic growth with the help of PARDL in OECD and EU countries. According to the result of a bounds test, there is cointegration between the variables. The long- and short-term relationships between series were determined and the results taken from the analysis show that there is a positive effect on economic growth in those countries.
\end{abstract}

\section{Keywords}

Property Rights, Economic Growth, EU, OECD, ARDL Bounds Test Analysis

\section{Introduction}

One of the basic concepts of economics is the analysis of how limited resources are preserved in spite of eternal human needs by means of property rights. This is because the effective distribution of limited resources depends on to whom their usage rights belong. When a transaction is executed, it can be observed that there is a change in property rights. The exchange carried out on the market is the value of the property rights that determine the price. In an economy in which there is no transaction cost and mass behavior occurs easily, it does not matter whether properties and production factors are used by their owners or hired (Demsetz, 1967).

${ }^{1}$ Bilecik Şeyh Edebali University, Department of Economics, Faculty of Economics and Administrative Sciences, Bilecik, Turkey. E-mail: ceyhun.haydaroglu@bilecik.edu.tr. 
For a long time, economists have been trying to explain the differences between growth rates observed in different countries. It is unfortunately still an ongoing important problem that countries cannot reach the growth rates to which they aspire. It has become necessary to revise growth rates in countries and international institutions have given advice to developing countries which has not worked. It is now clear that even good policy suggestions cannot help some countries achieve the results they want due to badly coordinated institutional structures (Knack and Keefer, 1995). Therefore, in recent years some empirical studies have been carried out that were especially focused on the effects of institutional structure on growth rates. Institutional structure has played second fiddle for a long time, but new institutional economists and liberal economists (Hayek, 1973; Coase, 1998; North, 1991) have again highlighted the importance of structures in development. Institutional structure has undeniable importance due to the work, investment and protection instinct that it provides to individuals. But the most vital effect of property rights is spreading economic and political power throughout society by the free use of resources which have been released from government monopoly.

How property rights are described as an institutional structure under different political systems is important not only in terms of economic relations but also social relations. The relationships which individuals build up among themselves will operate in accordance with the rights which the society determines. At this point, the political system chosen also has significant importance in determining the boundaries of government: a government that is powerful in terms of ensuring the formation and execution of property rights is also powerful when violating the same right. A government which enjoys monopoly rights leaves its citizens open to abuse, so it is vitally important that property rights should be limited for the government by means of protective laws for individuals. Property rights mean that the rights of a government when making decisions about resources is limited by the handing over of the rights of usage to ordinary citizens. The importance of limiting government has been repeated by many philosophers throughout history. Starting with Montesquieu (1748) and Smith (1776), and continuing today with Acemoğlu et al. (2001), Easterly and Levine (2003), Glaeser et al. (2004), Rodrik et al. (2004), La Porta et al. (2008), many important economists have argued that political structures restricting government power increase economic growth. If governments do not clearly describe the rights which they give to their citizens, it means that they are prone to kill the goose that lays the golden egg and there will be equalitarian organization among the citizens. When the power of government is restricted, it will strengthen instead of weaken it.

In the 1980s, growth rates in some eastern Asian countries took the lead in breaking some traditional expectations. Contrary to the studies mentioned above, there is a view which claims that growth in income and human capital provide progress in institutional structure. In fact, it was claimed for the first time by Lipset (1960) that development creates good institutional structure and that it is necessary to establish the causation in this manner. Lipset's study, which is based on that of Aristo, states that educated people use ratings or agreeable, peaceful, ways to solve their problems instead of resorting to violence. An increase in the level of income will raise the education level of individuals and this will foster a more peaceful and stable environment and progress in institutional 
structure will be observed. Lipset's hypothesis, in which he says that economic growth improves the institutional structure in countries, has been supported by Przeworski and Limangi (1993) and Barro (1990) by means of empirical testing.

The New Institutional Economy School has led us to understand the improvement process of societies better by adding institutions and property rights into the analysis. The studies carried out have revealed that there is an increase in welfare in those societies where entrepreneurs feel that both they and their investments are safe and in which laws and rules are applied; on the other hand, there is weakness in the development of those societies where agreements are weak or lacking (Rodrik, 2004). Property rights form economic change and make contributions to physical, human and intellectual property formation in the light of formal and informal rules which form themselves. Sometimes, the benefit-cost change in the economic structure makes a difference in the property regime. No matter on which reason it is based, that a government's rules determine the individual's limits of property usage means that there will be dominant factors, both economic and political, at play in the defining of the right.

This empirical study focuses principally on the relationship between economic growth and property rights. The OECD has been working with its own members as well as with non-member governments and other organizations to restore economic stabilization and expansion, with a central part of this effort including the position that governments must be cautious not to reduce property rights as they seek ways in which to strengthen and revitalize their economies. In other words, nations are strongly encouraged to continue to support and promote property rights while implementing domestic economic policies. Clearly, the concern of the OECD in this context is that a reduction in property rights will result over time in diminished economic growth.

Today, it is said that one of the most important factors behind different growth rates is each country's choice with regard to property rights. This study aims to analyze different property rights and their role in economic development with reference to the Institutional Economy School. In the modern world, especially thanks to new technology, another factor which should be carefully considered is that changes in active prices exert pressure for change on the property structure. The aim of this study is to analyze, for the period 2007-2014, the relationship between property rights and economic growth with the help of PARDL technique in OECD and EU countries. Accordingly, the study has five main parts. In the first part, the relationship between property rights and economic growth is briefly discussed. The second part contains a summary of the literature about the subject. In the third part, the methods and data used in the application are explained. In the fourth part, the application data is presented. The study is brought to an end with the fifth part, in which the data is evaluated.

\section{Description of property rights and their survey}

Property rights have important effects on national and individual welfare. Countries can reach a totally different position in society by changing the property rights system. As with other rights, property rights cannot be applied without being accepted by the overall society. Different societies accept different systems because of different environmental 
and social terms in their countries. Every society reacts to events in accordance with their experiences in the past. In spite of the fact that rules have some basic common aspects in each country, their diversity is thanks to their past experience.

It has become necessary to form some rules governing the usage of resources that are not sufficient in the environment in which people live. Property rights are different arrangements formed in order to enable individuals to use available resources effectively. The rights in question determine the reaching conditions for some resources of an individual or a group or organization. Personal property, unlike others, enable individuals to legate or exclude others and use different sanction mechanisms in the use of rights (Alchian and Demsetz, 1973).

There are two conditions for property: resources should be in limited amounts and they should be desired. For a resource to be limited means that specific numbers of individuals can use them. Those who value the resource greatly are ready to pay a price for holding it in their hands (North, 1991).

In classical economics, property rights have not been subject to analysis; it is assumed that individuals possess goods directly and resources change hands in such a way as to ensure the most efficient allocation with zero transaction costs. However, in real life the transaction costs of individual rights remain far from presenting a complete picture. For example, the negative externalities caused by air pollution, due to the large number of affected people, have often been ignored in terms of compensation for the injured party. However, individuals may sometimes deliberately not want to take over the ownership of resources. This can occur when transaction costs are compared with earnings expected to be obtained and the returns are low (Demsetz, 1967).

When economic resources are under the control of individuals, it is important for them to retain a perspective on the use of those resources at any particular time. When individuals have full control of a specific resource, they do not hesitate to make long-term investments to increase the value of the resource by thinking long term. On the contrary, when it is not obvious who is in control or the duration of the period of possession, the use of such resources may result in the taking of decisions which are to the detriment of future generations. If individuals do not have the right to exclude others in the use of their rights, they will not have any particular desire for improvement.

When we look at the evolution of property rights in various countries, relative to rarity it is possible to observe that the resources of the state enjoyed the first property arrangements. If other resources are rarer than land, rules on property are not created in the first place. For example, Feder and Feeny (1991) studied the development of property rights in Thailand. The scarce resource there was labor in the 19th century, which resulted in the discovery of very clearly defined rules in this area. Increases in population density then led to the development of rules on the ownership of land after land became scarce in Thailand.

Property covers all objects that are subject to ownership. One of the most important reasons for the formation of intellectual property rights on objects is the limitation of resources. The presence of limited resources requires them to identify their users in order to be used effectively. A property rights system is the ability of individuals to use tangible and/or intangible assets in accordance with their wishes. To hold the property rights of any entity 
means that you will be able to make decisions about its future, determine the terms of use and that you have the legal framework to deprive others, if so desired, of using the entity. At no time can property structure not be said to be more effective than others, such as an ownership of a type that does not require the exclusion of others. Over time, as a result of changes taking place in asset prices, it is observed that ownership structure can also change due to changes observed in alternative costs. The factors underlying the change in the selected institutional structure are, according to Dahlman (1980), primarily transaction costs, then the priorities of those groups active in decision-making. Transaction costs are, according to Williamson, bounded rationality and opportunism, and are due to the homogeneity of the asset (Williamson, 1985). Therefore, it is important to show the change in the cost of efficient technology that allows institutional change. Decline in transaction costs make it possible to switch to a more efficient corporate structure. However, the structure of the society and traditions put pressure on the exchange rate.

Under the current economic structure, when we want to maximize the values that we have, we can achieve this aim by means of ownership of objects. Of course, being free to transfer possessions to a selected person as soon as it has been agreed and for everyone to have an equal chance to access the property are indispensable conditions for ensuring conditions under which the values we obtain will be maximized. We have a right, aside from humanitarian reasons, for the restrictions imposed on the transfer of property not to prevent such property from being transferred to those who value it the most. The imposition of restrictive rules may result in the reduction of investments and the willingness to work (Uzun, 2009).

The measurement of property rights or the determination of them as a specific value is a major problem, because the acquisition of property rights or the obtaining of quantitative indicators from the data is difficult. But it is possible to determine how property rights illustrate a structure by observing the economic and social fields. Today, the main method used to determine the degree of property rights is survey data. Transnational comparative analysis and indicators commonly used in empirical studies are conducted by international organizations and private researchers survey indexes are created as a result. These studies are prepared by private companies, international organizations, business leaders, citizens face-to-face or from data obtained as a result of interviews conducted by telephone (Mocan, 2004). The "International Property Rights Index (IPRI)" is also used. This index was created with the property rights of the alliance's efforts and was first published in 2007. According to the index, countries are evaluated in three categories, namely: political/legal property rights, property rights and intellectual property rights in the material.

The variables and method of calculation of the IPRI report can be summarized as follows. There are 11 variables under three main headings in the index (IPRI, 2014):

Legal and Political Environment (LP): The soundness of the legal and political system of a country; this is considered its point of view on the importance and protection of its intellectual property rights. Independence of the judiciary is covered by this title, along with the level of confidence in the courts, political stability and variables on the taking of bribes. 
Physical Property Rights (PPR): This variable includes three sub-variables of great importance in terms of the protection of private property rights. These are: the protection of physical property rights, property registration and getting into debt.

Intellectual Property Rights (IPR): The intellectual property protection and patents of the country, applicable policies and activities regarding trademarks and copyrights. This is in turn divided into four sub-branch: the protection of intellectual property rights, patent protection, theft of copyright and protection of trademarks.

The IPRI's rating scale is from zero to 10 . While 10 represents the most powerful level in terms of the protection of property rights, zero indicates that there is no security with regard to property rights in the country concerned. Besides the overall scale, the core element and each variable is given a rating of between zero and 10 .

\section{Theoretical framework and literature review}

Institutional economics of property rights constitutes one of the theoretical tool used to create a fundamental incentive structure as created by the institutional structure. Creating differences in resource allocation differences concerning the protection and enforcement of intellectual property rights can lead to cross-country differences in economic growth (North, 1990; Libecap, 1989; Tornell, 1997; Torstensson, 1994). In cases where good protection of property rights are not applied, resources can be allocated to non-productive areas (Furubotn and Pejovich, 1972). The causes of intercountry economic performance differences that occur in the ownership regime differences (Leblang, 1996; Tornell, 1997) is an approach supported by the empirical studies.

The right of ownership over any goods or resources, such as resources or property consumption covers other transfer and control rights (Leblang, 1996). According to North (2002), the property rights "of individuals, their labor rights they have acquired the goods and services on their own" are defined and seen as a function of the institutional framework. For North and Weingast (1989), the security and continuity of intellectual property rights are key elements underlying modern economic growth, as entrepreneurs lack any incentive to invent or innovate unless they have the right to adequate control over the returns from the property. For Rodrik (2000), the control concept is one of the very basic concepts of property: as long as they ensure the right to control, formal property rights are claimed to be significant. The legalization of property rights is not in itself a sufficient condition for the protection of property rights.

Tornell (1997) has approached the issue of the protection of property and the property rights regime from a historical perspective. In this context, the immaturity of the economy will lead to a lack of or the underdevelopment of institutions for the protection of private property; it is argued that, in order to protect private profits in the economy, a shift toward private ownership will emerge and will much improve or enrich compared to the cost incurred from creating the necessary institutions. According to Tornell, sufficient economic wealth will make rent-seeking activities profitable and increasing their redistributive activities will lead to the emergence of the fiscal deficit, the deterioration of the prevention of invention and labor relations. 
In the neoclassical growth model, the emphasis has been on physical capital investments. The endogenous growth models are seen as a source of human capital to economic growth. But here there is an implicit presumption that private property rights are well protected, in other words, engaging in productive activities is encouraged. This assumption, even if it is assumed to be true for developed countries, can be seen to be unacceptable for the majority of developing countries. Thus, differences that occur in the structure of property rights have led to differences in the level of long-term economic growth (Torstensson, 1994). On the other hand, neoclassical economics assumes that it has a far from complete information exchange process and friction and the environment in which it operates individual economic well-defined property rights. As a result, it is considered that transaction costs are zero in the neoclassical world and individual and social benefits cannot be separated from each other (North, 2002; Leblang, 1996).

The new institutional economics tradition has seen the protection of property rights as a key determinant of economic growth. In this context, the relationship between economic growth and the protection of property rights are established through two channels: the transaction cost and efficient resource allocation. North (2002) defined the total production cost, including the resource inputs such as labor and capital, to change the property of the physical properties and processes and saw the transaction costs as a part of these. In this context, Barzel (1997), defined transaction costs and the protection of rights as the economic costs associated with obtaining and transfers.

The protection of property rights is established by the relationship between the economic growth channel and transaction costs. The complexity of the economic process and uncertainties about the future requires contracts to be very detailed and to cover both existing and potential situations. However, the cost of the operations performed in this way will be very high. In addition, the preparation of a contract taking into account all possible cases is impossible in practice. To reduce transaction costs, property rights have to be protected and defined in a good way (Mahoney, 2004). In cases where there is weak protection of the control and ownership of the rights along with high transaction costs, investors will not take the decision to invest. Therefore, the high cost and a lack of process that may arise regarding the protection of intellectual property rights may, by reducing physical and human capital investment, lead to negative impact on economic growth.

Another channel of the relationship established between property rights and economic growth is related to the effective allocation of available resources. Here, the argument which is put forward is based on the assumption that the human and physical capital of well-preserved property rights or production factors will be used effectively and will affect economic growth positively (Furubotn and Pejovich, 1972). Torstensson (1994), evaluated that the efficient resource allocation of property rights has a direct effect on economic growth. In cases where property rights are effectively protected, human capital will be directed towards productive activities, which in turn will improve the existing technology and this suggests that economic growth will be positively affected. Torstensson (1994) argued that, in the absence of effective property rights protection systems, human capital will lead to rent-seeking and redistributive activities; and these activities, due to lack of productivity, will negatively affect economic growth. Khan (1995) has said it is 
property rights that have driven human capital to pursue productive activities because they effectively protect the expected returns. He argued that a patent system providing for the protection of property rights will improve inventions and technology and therefore there will be a positive impact on economic growth.

The relationship between economic growth and the protection of property rights, not only as human capital, but also as a factor of production, has an effect on economic growth by affecting physical capital allocation decisions. Furubotn and Pejovich (1972) argued that the identification of intellectual property rights in a good way will reduce uncertainty and also lead to resources being effectively used or allocated.

There is no doubt that clearly-defined property rights have greater importance in terms of the withdrawal of foreign, rather than domestic, investors, capital and advanced technology. Because in this way a more secure area of activity for foreign investors can be created and it will be possible to address long-term investment goals. From this perspective, it is becoming important for those countries in need of outsourcing in terms of economic development goals, to place more emphasis on institutional arrangements and raise their standards to international levels in order to attract more investment (Ata and Şahbaz, 2013).

Ownership structure affects economic incentives and encouragement in the community and these impulses and incentives determine individual needs, preferences and requirements. Thus, individuals who are directed by institutional structure would have a role in the creation and economic structure change by changing their economic behaviours accordingly (Nee, 2003). The existence of property rights is one of the important factors that pushes people from the informal market to register on the market (Leblang, 1996). Individual responsibility increases along with property rights. The illegal and the informal sector is replaced with a legal and formal economy. The presence of a sufficiently welldefined and protected property rights system may lead to a reduction in illegal economic activities in the market by providing guarantees for informal exchanges (Dinçer, 2007). It is said that the emergence of the liberal economic doctrine of guaranteeing property rights affects economic growth and development process positively. It has lately been attempted to prove this idea, championed in theory for years, by means of empirical studies. The general belief, according to these studies, is that countries where property rights are guaranteed fully and effectively, are in a better position than other countries in terms of economic growth and in many other ways, including annual income per person. Goldsmith (1995), examined the relationship between democracy and property rights and growth in his study. He has examined the correlation between the four indices showing the corporate structure, Freedom House democracy index, Heritage Foundation's property rights index, including the repayment of the credit risk rating, and Euromoney Institutional Investor countries. In this study, depending on the property rights index, dummy variables have been used to represent the institutional structure model and whether the political rights index and country had socialist regimes in the past. Given the other economic factors in the results, the study of democracy and the importance of intellectual property rights regime has revealed that they have recorded better growth. 
Dinçer (2007) has tested the relationship between property rights and economic performance. The effect of human and physical capital on economic growth in economies which provide weak, medium and high levels of property rights. The findings show that human and physical capital have a weak positive effect on economic growth when the economic structure provides less assurance of property rights. On the other hand, when there is higher security for property rights, the positive effect increases.

Richardson (2005) revealed, in a study conducted on Zimbabwe, that the main cause of the economic collapse that occurred in the country during 2000-2003 was the change in the ownership system. Restrictions on common property led to a negative impact on economic growth, with guarantees on private land in the property system coinciding with a linear relationship to economic growth.

Branstetter et al. (2005), have revealed that, multinational companies implement more technology transfer to the countries that have high level of protection of property rights, in research that covers 16 countries between the years 1982-1999. Johnson et al. (2002) found that when the investments were made in an economy where property rights were guaranteed, economic growth was positively affected accordingly.

Clague et al. (1999), discussed how the assurance of ownership over assets in the economy affected economic performance for the period from 1970 to 1992 in 95 countries. Overall, they found that economic growth increased alongside property guarantees on financial assets.

Torstensson (1994), in general addressed the relationship between property rights and economic growth. The horizontal section examines the econometric methods used in 68 developed and developing countries for the period 1976-1985. As a result, it is emphasized that, when the property rights are not protected, human capital efficiency and investment rates are affected negatively, but when property rights are protected, economic growth occurs in line with the increase in human capital efficiency and investment rates.

Tornell (1997), examined the relationship between different property regimes and economic performance. According to the findings, the progression towards a private property system of common property systems enhances economic performance.

Svensson (1998) and Torstensson (1994) examined intellectual property rights in general. A cross-sectional analysis of 101 countries in the 1960-1985 period was used. Econometric analysis concluded that well-defined property rights were the cause of low investment. The author in this case connected this to two interrelated effects. First, well-defined property rights may cause a move away from taxed activities of sources. This will reduce tax revenues and therefore the government's ability to manage the country in the future. The second effect is the cost of creating a legal infrastructure. As a result, the relationship between property rights and economic growth are discussed in the framework of political instability and investments. Investment and growth rate differences between countries are primarily linked to how political instability caused the failure of exactly-defined property rights. Political instability leads to low levels of investment and growth. In this context, a well-defined property rights system has an accelerating effect on economic growth by preventing political instability. 
The economic case for secure property rights is that growth depends on investment. However, investors do not invest if there is a risk of government or private expropriation (Everest-Phillips, 2008; Besley and Ghatak, 2009; Acemoğlu et al., 2005). This is confirmed by Kerekes and Williamson (2008) who identify a strong, positive relationship between secure property rights and investment, again controlling for variables such as geography, religion and legal and colonial origin. Green and Moser (2012) also support the link between secure property rights and investment at the firm level. Their results indicate that secure property rights, in the form of formalized land titles, are important for the emergence of large firms, at least in the case of Madagascar.

Ojah et al. (2010) look at the roles and interactions of property rights and internal/external finance channels on investment across 860 firms in Kenya, Tanzania and Uganda, using the World Bank's Investment Climate Assessment data, where the proxy for secure property rights is an effective legal environment, measured mainly by judicial enforcement of property rights. Analysis by Keefer (2007) looked at the role of different factors in China's accelerated growth from the 1980s. This analysis found that, despite the lack of formal property rights, the government had an important role in creating a safe investment climate through support to enhance investor returns and credible moves to reduce the risk of expropriation.

Chong and Calderón (2000) obtained strong evidence for two-way causality: growth increases the ICRG measures, but institutional quality, as measured by ICRG values, increases growth rates. Because the ratings are subjective assessments by experts, it is possible that the ratings are influenced by knowledge of recent economic performance. This is supported by more recent evidence from Mijiyawa (2009), who undertook crosssectional analysis over the period 1970-2005 with a sample of 142 countries and found that the quality of private property rights institutions is positively affected by increases in GDP per capita. This two-way causality also seems to exist at a more micro level (Green and Moser 2012). In addition, the relationship between property rights and growth may be non-linear (Bose et al., 2012): stronger enforcement of property rights raises growth up to a certain point before growth begins to decline.

Besley and Ghatak (2009) refer to the role of more secure property rights in facilitating market transactions or trade in assets via the deepening of rental or sales markets in land, thus increasing the mobility of assets such that all land is fully utilized and is highly productive. Keefer and Knack (2002) argue that a higher degree of social polarization increases the likelihood of extreme policy deviations, making property rights less secure and thus negatively affecting growth.

Valeriani and Peluso (2011) analyze the impact of institutional quality on the economic growth at different stages of development by employing a panel over the period 1950-2009 for 181 countries. They found a positive impact of institutions, measured by civil liberties, quality of government and number of veto players, on economic growth. They also show that institutions are more effective in developed countries as compared to developing countries. Chauffour (2011), using data for more than 100 countries over the period 1975-2007, found that institutions, measured by economic freedom and civil and political liberties, determine why some countries achieve and sustain better economic outcomes. 
Jacoby, Li, and Rozelle (2002) empirically confirm the positive role of security property rights on land investment using village data in China.

The empirical evidence on the role of property rights in economic growth also revealed mixed results, confirming the conflicting theoretical predictions. Empirical studies that concluded that property rights had a positive effect on economic growth include Falvey et al. (2006), Gould and Gruden (1996), Park and Ginarte (1997), Thompson and Rushing (1999), Kanwar and Evenson (2003), and more recently, studies by McLennan and Le (2011), Andrés and Goel (2011), and Sattar and Mahmood (2011). More recently still, Hudson and Minea (2013) concluded that the effect of property rights on innovation was more complex than previously thought, displaying important nonlinearities depending on the initial levels of both property rights and per capita GDP. Other empirical works on property rights and economic growth were skeptical about, or completely against, the positive effect of property rights. Examples include a study by Lerner (2009), who found little positive impact of protecting patents on innovations and economic growth. Boldrin and Levine (2009) argued that protecting innovative activities was only important for the discovery period, and concluded that in the long run, protecting property rights might be damaging because of diminishing returns and the extent to which less developed economies could imitate the imported products. A more recent study by Samuel (2011) found that the impact of property rights on economic growth was actually negative for the countries of Sub-Saharan Africa (SSA), because most innovation in SSA might be imitative or adaptive in nature; thus, providing stronger property rights might have protected foreign firms at the expense of domestic firms of SSA.

A more recent study by the OECD has further quantified the benefits of IP protection for foreign direct investment, not just with respect to patent protection but also copyright and trademark. A $1 \%$ increase in the strength of patent protection correlates to a $2.8 \%$ increase in FDI. A similar increase of trademark and copyright protections correlates to a $3.8 \%$ and a $6.8 \%$ increase in FDI, respectively (Cepeda, 2010).

Cebula (2011) examines the impact of the economic freedom on economic growth in the OECD countries for the period 2003-2007 and concludes that economic growth is positively correlated with monetary freedom, business freedom, investment freedom, labor freedom, fiscal freedom, property rights freedom, and freedom from corruption.

Pourshahabi et al. (2011) investigate the relationship among FDI, human capital, economic freedom and growth in the OECD countries over the period 1997-2007 by using panel data analysis. Their research concluded that more economic freedom can improve economic growth, both directly and indirectly. It can indirectly improve economic growth by promoting incentives, productive effort and the effectiveness of resource use.

\section{Methodology and data}

Economic time series usually have non-stationary processes (Johansen and Jesulius, 1990). At the end of an analysis performed using a non-stationary time series, there can be a spurious regression problem (Granger and Newbold, 1974). The process of compensating for this is carried out in order to ensure consistency. However, this process can eliminate the series in the series, while it causes information loss between relations (Tarı and Y1ldırım, 
2009). Therefore, stable composition of the series is not stationary in levels that could be detected and refers to the cointegration analysis that can be determined by expressing it econometrically (Eriçok and Yılancı, 2013).

In this study, the Panel Border Test Analysis was used to investigate the effects on the growth of the index of property rights in OECD and EU countries. In estimating the effect in question, the annual time series of the 2007-2014 period has been used to group the countries examined. Growth data was collected from the World Bank (WB), and property rights data was collected from the Property Rights Alliance Organization's official website. Growth figures constitute the dependent variable under study and the model was taken as the GDP per capita of the country. The value of the property rights defined as the index values is between zero and 10 . The value 10 represents the most powerful level in property rights protection, zero shows that there is no security of property rights in the countries mentioned.

In this study, the following basic equation was used to investigate the effects on the growth of property rights:

$$
\mathrm{LBY}_{t}=\alpha_{0}+\alpha_{1} \mathrm{LPR}_{t}+\varepsilon_{t}
$$

Here, $\mathrm{LBY}_{t}$ shows logarithmic per capita growth rate in period $t, \mathrm{LPR}_{t}$ shows logarithmic value of the property rights index in period $t, \alpha_{0}$ shows constant of model and $\varepsilon_{t}$ shows the error term of the model.

Thanks to the bounds testing approach based on the Wald or F-statistic variables developed by Pesaran et al. (2001), it is possible to test whether or not there is a cointegration relationship (Yaprakl1, 2010). The Autoregressive Distributed Lag ARDL bounds test approach has several advantages when compared to the alternative cointegration test. The most important advantage of the ARDL bounds testing approach is that the variables included in the analysis $I(0)$ or $I(1)$ are applied regardless of what they are (Pesaran et al., 2001). Thus, in the bounds testing approach, there is no need to determine a priori the degree of integration of the variables (Narayan and Narayan, 2005). Moreover, when the power of the unit root tests is low and related literature in unit root and cointegration analysis is examined, it can be observed that the pre-test has problematic results (Pesaran, 1997). The second advantage of the ARDL bounds testing approach is that it has better statistical properties, because it uses unrestricted error correction models (UECM) when compared to the Engle-Granger method (Narayan and Narayan, 2005). Another important advantage is that it is applicable to studies with a small sample. Also, when there are a small numbers of observations, the bounds test approach gives more reliable results than the Engle-Granger and Johansen cointegration test (Narayan and Smyth, 2005).

The ARDL bounds testing approach basically consists of three stages. In the first step, among the parameters included in the analysis it is tested whether there is a long-term relationship or not, whether there is a cointegration relationship between these variables, and in the following stages, respectively, whether long- and short-term elasticity are obtained (Narayan and Smyth, 2006). UECM generated in the first stage for ARDL bounds testing approach is located in Equation 2. These models are expressed with an adapted version of the study. 


$$
\begin{aligned}
\Delta \mathrm{LBY}_{t}= & \alpha_{0}+\Theta_{1} \mathrm{LBY}_{t-1}+\Theta_{2} \mathrm{LPR}_{t-1}+\sum_{i=1}^{p} \varpi_{1 i} \Delta \mathrm{LBY}_{t-i}+ \\
& +\sum_{j=0}^{p} \beta_{1 j} \Delta \mathrm{LPR}_{t-j}+\varepsilon
\end{aligned}
$$

The P-value in equation 2 in the model represents the appropriate length of the lag. To decide on the p-value, information criteria are used. In the ARDL bounds testing, after determining lag length, in order to investigate the existence of a cointegration relationship between the variables included in the analysis, $H_{0}: \Theta_{1}=\Theta_{2}=0$ basic hypothesis is tested by using an F test (Narayan, 2005). However, in order to test, the standard F test used to test the basic hypothesis has a non-standard distribution for several cases (Narayan and Narayan, 2005). Narayan and Narayan (2005) state that in their study, (i) ARDL model of the variables $I(0)$ or $I$ (1) whether, (ii) the number of variables and (iii) the constant term of the ARDL model and/or trends is expressed in the contents. Therefore, test-critical values which should be compared with the statistics are tabulated by Pesaran et al. (2001). These critical values are composed of two parts. Whether the variables are $I(0)$ or $I(1)$ the critical values for the lower and upper limits are determined. If the calculated F statistic value is greater than the critical value, the upper limit of the basic hypothesis indicates that there is no long-term relationship between the variables to be rejected. If the calculated $\mathrm{F}$ statistic value is smaller than the lower limit of critical value, the basic hypothesis can be rejected. If calculated F-statistic values between lower and upper the limits, this decision cannot be taken and it is recommended that other cointegration tests taking into account the degree of stability variables should be used (Y1lanc1, 2012).

With the help of a Bounds test analysis, long- and short-term coefficients can be estimated. The sum of the coefficients, the lagged independent variable coefficients which are multiplied by negative mark of the dependent variable, can be reached in the long-term coefficient by removing one from the total of the dependent variable (Bardsen, 1989; Yllanc1, 2009, Şimşek and Kadılar, 2005). The ARDL model is used to estimate the long-run relationship between the variables is shown below:

$$
\mathrm{LBY}_{t}=\alpha_{0}+\sum_{i=1}^{n} \alpha_{1 i} \mathrm{LBY}_{t-1}+\sum_{i=0}^{m} \alpha_{2 i} \mathrm{LPR}_{t-i}+\varepsilon_{t}
$$

Coefficients of the current period represents the difference of the arguments directly to the short-term coefficients (Y1lanc1, 2009). In this context, the short-term relationships between variables was investigated by an error correction model based on the ARDL approach. A model of a short-term relationship is shown below:

$$
\Delta \mathrm{LBY}_{t}=\alpha_{0}+\sum_{i=1}^{n} \alpha_{1 i} \Delta \mathrm{LBY}_{t-1}+\sum_{i=0}^{m} \alpha_{2 i} \Delta \mathrm{LPR}_{t-i}+\varphi \mathrm{HDT}_{t-1}+\varepsilon_{t}
$$


The $\mathrm{HDT}_{t-1}$ variable referred as the error correction term in equation 4 , is the previous term value of the model series obtained from ARDL model. These variables belonging to the coefficient $\varphi$ indicate how much of the instability in the short term can be corrected in the long term.

AIC is used in determining the length of the lag in the ARDL model. In determining the length of the lag, the method described by Kamas and Joyce (1993) was used. Accordingly, only the number of the lag which has been carried out according to their own lagged values of the regression and the smallest AIC value of the dependent variable on the maximum lag length is determined before the first selected, the selected number of lags of dependent variables are kept constant, and the smallest AIC value creating regression with all the lags of the first independent variable is assigned as the number of lag of this argument. The same process is performed for the other variables.

\section{Findings of application}

Whatever the test method applied, panel data analysis usually begins with stationary panel unit root tests attempting to show what variables are taken into account in the model. Table 1 shows the unit root test results related to the series used in the model.

Table 1: Panel unit root test results

\begin{tabular}{|c|c|c|}
\hline Method & Name of the variable & Test Statistics \\
\hline \multirow{3}{*}{$\begin{array}{l}\text { Im, Pesaran ve } \\
\text { Shin W statistics }\end{array}$} & LBY & 3.89697 \\
\hline & $\Delta \mathrm{LBY}$ & $-6.8713^{*}$ \\
\hline & LPR & $-3.1952^{*}$ \\
\hline \multirow{3}{*}{$\begin{array}{l}\text { ADF-Fisher } \\
\chi 2 \text { Statistics }\end{array}$} & LBY & 45.4527 \\
\hline & $\triangle \mathrm{LBY}$ & 205.1482 \\
\hline & LPR & $143.0765 *$ \\
\hline \multirow{3}{*}{$\begin{array}{l}\text { PP-Fisher } \\
\chi 2 \text { Statistics }\end{array}$} & LBY & 32.5863 \\
\hline & $\Delta \mathrm{LBY}$ & $231.9723 *$ \\
\hline & LPR & $152.8687 *$ \\
\hline
\end{tabular}

Note: For ADF-Fisher and PP-Fisher statistics, $\chi 2$ distribution is valid, for Im-Pesaran-Shin W statistics, asymptotic normality assumption is valid. $\Delta$ processor shows that the first difference of the variable is taken. *,** and *** expressions show that the related variable is meaningful in the $1 \%, 5 \%$ and $10 \%$ significance levels, respectively.

According to the results of the panel unit root test, while their logarithmic growth figures for the first difference value per person are stable, the logarithmic property right is stable according to the worth of the level. Therefore, it is appropriate to use the PARDL test to investigate the long-term relationship for these two variables.

Table 2: Determining the proper lagging lengths for the bound test

\begin{tabular}{|c|c|c|}
\hline Lagging number $(\mathrm{m})$ & AIC & SIC \\
\hline 1 & -1.5795 & -1.5513 \\
\hline 2 & -1.5307 & -1.4952 \\
\hline 3 & -1.5789 & -1.5508 \\
\hline 4 & -1.6198 & -1.5796 \\
\hline
\end{tabular}


Table 2, which is calculated by lag taking into account the AIC and SIC to be used in the bounds test shows the appropriate lag length. Accordingly, both for AIC and SIC the appropriate lag length was found to be 4 . The appropriate length of lag between series started after it is started to study cointegration relationship between series by bounds testing approach. Table 3 shows the bound test results.

Table 3: Bound test results

\begin{tabular}{|c|c|c|c|c|c|}
\hline \multirow{2}{*}{$* *$} & F statistics & \multicolumn{2}{|c|}{ \%1 Critical Value } & \multicolumn{2}{c|}{ \%5 Critical Value } \\
\cline { 3 - 6 } & & Lower limit & Upper limit & Lower limit & Upper limit \\
\hline 1 & 24.4365 & 5.29 & 6.24 & 3.67 & 4.79 \\
\hline
\end{tabular}

Note: * $k$, represents the number of the independent variables in the (2) number of equation. Critical values are taken from the Table CI(iii) at Pesaran et al. (2001).

Table 3 shows the calculated $F$ statistical value, after estimating with the 4 lag of the (2) number of the equation, and the critical value which is taken from the Pesaran et al. (2001). These critical values are valid for a $1 \%$ and $5 \%$ significance level. Because the calculated F-statistic is bigger than the upper limit of $1 \%$ significance level, it is possible to say that there is a cointegration relationship between the variables. In this context, the PARDL model used to determine the relationship between the long- and short-term studies.

Table 4: Determining the proper lagging lengths for the long-term and short-term ARDL model

\begin{tabular}{|c|c|c|c|c|c|c|c|c|}
\hline & \multicolumn{4}{|c|}{ Long-Term } & \multicolumn{4}{c|}{ Short-Term } \\
\hline & \multicolumn{2}{|c|}{$\begin{array}{c}\text { Dependent } \\
\text { variable }\end{array}$} & \multicolumn{2}{c|}{$\begin{array}{c}\text { Dependent and } \\
\text { independent } \\
\text { variables together }\end{array}$} & \multicolumn{2}{c|}{$\begin{array}{c}\text { Dependent } \\
\text { variable }\end{array}$} & \multicolumn{2}{c|}{$\begin{array}{c}\text { Dependent and } \\
\text { independent } \\
\text { variables together }\end{array}$} \\
\hline Lag (m) & AIC & SIC & AIC & SIC & AIC & SIC & AIC & SIC \\
\hline 1 & -0.3521 & -0.0910 & -1.5397 & -1.5305 & -1.3721 & -1.3601 & -1.6085 & -1.5793 \\
2 & -1.3778 & -1.3696 & -1.5014 & -1.4812 & -1.3085 & -1.3043 & -1.5696 & -1.5525 \\
3 & -0.1101 & -0.1295 & -1.5188 & -1.4993 & -1.4678 & -1.4647 & -1.5678 & -1.5512 \\
4 & -0.2365 & -0.2115 & -1.5496 & -1.5278 & -1.4956 & -1.4959 & -1.6213 & -1.5891 \\
5 & -0.3951 & -0.4428 & -1.5589 & -1.5278 & -1.5997 & -1.5906 & -1.6507 & -1.6223 \\
6 & -0.4927 & -0.5065 & -1.5646 & -1.5406 & & & & \\
\hline
\end{tabular}

In order to examine the long-term relationship between the variables used in the study (3), the number indicates the length of the lag in obtaining the ARDL model AIC and SIC aid. According to the results of this analysis, the maximum lag length is taken to be 4,2 and, if taking into account the dependent variable with the dependent and independent variables, an appropriate lag length of 6 was observed. Thus it was decided to estimate the ARDL $(2,6)$ model.

According to the results of this analysis in which the maximum lag length is taken as 5, when we consider both the dependent variable dependent and independent variables, it would be appropriate that the lag length was taken as 5 . Thus it was decided to estimate the $\operatorname{ARDL}(5,5)$ model. 
Table 5: Estimation results of the long-term dynamic ARDL (2, 6) model and short-term dynamic ARDL $(5,5)$ model

\begin{tabular}{|c|c|c|c|c|c|c|c|}
\hline Variable & Coeff. & t-stat. & Prob. & Variable & Coef. & t Stat. & Prob. \\
\hline $\mathrm{C}$ & $0.4521 *$ & 8.1287 & 0.0000 & $\mathrm{C}$ & 0.0232 & 1.1521 & 0.3114 \\
\hline $\operatorname{LBY}(-1)$ & 0.7541 & 1.9852 & 0.6412 & $\Delta \mathrm{LBY}(-1)$ & 0.2578 & 1.0213 & 0.3021 \\
\hline $\operatorname{LBY}(-2)$ & $0.9496^{*}$ & 113.0156 & 0.0034 & $\Delta \mathrm{LBY}(-2)$ & $1.2254 *$ & 5.9585 & 0.0000 \\
\hline LPR & 0.0125 & 0.0598 & 0.3510 & $\Delta \mathrm{LBY}(-3)$ & $0.2399 *$ & 5.3952 & 0.0000 \\
\hline $\operatorname{LPR}(-1)$ & 0.2532 & 1.8141 & 0.4020 & $\Delta \mathrm{LBY}(-4)$ & 0.0621 & 0.8154 & 0.4365 \\
\hline $\operatorname{LPR}(-2)$ & $0.2498 * * *$ & 1.7423 & 0.0712 & $\Delta \mathrm{LBY}(-5)$ & $0.1256^{* * *}$ & 1.8965 & 0.0852 \\
\hline $\operatorname{LPR}(-3)$ & 0.1709 & 1.3274 & 0.3602 & $\Delta \mathrm{LPR}$ & 0.0733 & 0.0425 & 0.9754 \\
\hline $\operatorname{LPR}(-4)$ & $0.2504 * * *$ & 1.7385 & 0.0836 & $\Delta \operatorname{LPR}(-1)$ & 0.0123 & 0.5126 & 0.5962 \\
\hline $\operatorname{LPR}(-5)$ & 0.0624 & 0.7125 & 0.8245 & $\Delta \mathrm{LPR}(-2)$ & $0.4017^{*}$ & 4.1142 & 0.0000 \\
\hline $\operatorname{LPR}(-6)$ & 0.1654 & 0.7167 & 0.7012 & $\Delta \mathrm{LPR}(-3)$ & 0.0689 & 0.5193 & 0.6120 \\
\hline \multicolumn{2}{|c|}{$\mathrm{R}^{2}=0.9798$} & \multicolumn{2}{|c|}{$\mathrm{F}=6197.636$} & $\Delta \mathrm{LPR}(-4)$ & $0.2732 *$ & 3.1562 & 0.0019 \\
\hline \multicolumn{4}{|c|}{$\mathrm{F}_{\text {posibility }}=0.0000$} & & & & \\
\hline \multicolumn{4}{|c|}{ Long-term equation calculated with PARDL } & $\Delta \mathrm{LPR}(-5)$ & 0.1274 & 1.5679 & 0.1258 \\
\hline Variable & Coeff. & t-stat. & Prob. & HDT $(-1)$ & $0.9766^{*}$ & 7.2132 & 0.0000 \\
\hline $\mathrm{C}$ & $6.3785^{*}$ & 61.8163 & 0.0035 & \multirow{2}{*}{\multicolumn{2}{|c|}{$\mathrm{R}^{2}=0.3796$}} & \multicolumn{2}{|c|}{$\mathrm{F}=17.9856$} \\
\hline LPR & $1.9795^{*}$ & 34.2132 & 0.0008 & & & \multicolumn{2}{|c|}{$\mathrm{DW}=2.1423$} \\
\hline
\end{tabular}

Note: *, ** and *** expressions show that the related variable is meaningful in the $1 \%, 5 \%$ and $10 \%$ significance levels, respectively.

Table 5 ARDL $(2,6)$ shows the predicted results of the model. The long-term equation results in Table 5 indicated that the growth of the two terms showed a positive and statistically significant relationship between it and the lagged values. This suggests the need to consider the value of past growth in the forecasting of future periods. We also showed that the property rights of two and four periods of growth of the variables lagged values affected in any statistically significant way. However, the growth of the two- and four-term lagged value on property in the countries studied showed positive effects on it. The PARDL long period calculated from the model coefficients are positive and statistically significant at a $1 \%$ level of significance. Therefore, an increase in long-term growth in the index of property rights is a positive influence for growth.

In addition, Table 5 shows the estimated results of the error correction model. The results showed that there was a positive and significant correlation between the two, three and five terms of the growth-lagged value itself. With regard to the right to property, two and four-term growth of the lagged values has been shown to affect the growth in a statistically meaningful way. The coefficient of the error correction variable in the table are statistically meaningful in line with expectations. The results of the analysis show that there is positive affect of property rights on economic growth in the countries mentioned. 


\section{Conclusion}

Thanks to the dynamic structure of the property rights mentioned, we are today faced with a different concept of ownership. A century ago, individuals mostly exchanged tangible material objects; they are now exchanging copyrights, patents, and shares of material resources. In particular, the development of the service sector has increased the importance of personal skills and experience, with individuals now exchanging their expertise or knowledge for a certain monetary value. The exchange of goods that are subject to trade within the boundaries of property have expanded the definition to include these areas, providing protection in the legal system and the development of intellectual property rights.

In recent years, theoretical discussion of economic growth have focused on the growth of non-economic factors. In this context, the view that the main determinant of economic growth is countries' political, legal, institutional dynamics of social and cultural phenomena is discussed and defended by many scientists and thinkers. Here, the main argument is that institutional structures exert limitations on the behavior of economic actors, on their orientation and motivation. Thus, improvements in these structures contribute to the formation of well-being.

It is a commonly accepted view that institutional structure is one of the most important indicators of property rights and that there is an interaction between it and economic growth. Accordingly, better ensuring the security of property rights prevents the waste of resources, makes it possible to eliminate market distortions and creating positive externalities provides a positive contribution to economic growth. Additionally, the existence of guaranteed effective property rights reduces uncertainty in economic life and transaction costs, facilitates the bringing together of financial resources, accelerates technological knowledge flows and finally, results in economic growth in the long-term by encouraging entrepreneurs. In short, the institutional structures in which these rights are better protected are affective factors on outcomes such as productivity, economic growth, and economic development.

In this study, an index of property rights in the EU on economic growth in the OECD was investigated for the 2007-2014 period using the PARDL method. The coefficient of variable property rights is positive and significant in the EU and OECD, and the increase of property rights should be interpreted as a positive impact on growth. In this study, the relationship between property rights and economic growth was estimated by using the bounds testing method. In this context, in addition to the elements in the neo-classical growth model as a determinant of economic growth, property rights have also been included in the model. The main objective of the study is to test the relationship between economic growth between property rights. In this context, according to the estimated results of the study, an increase in property rights has been found to increase economic growth. So, in those economies where the guarantee of property rights is greater, the findings also show that there is a positive effect on economic growth.

Empirical growth literature has developed substantially over the past two decades, drawing on larger and richer databases and exploiting better econometric tools to explain 
cross-country differences in growth performance. This renewed interest in the empirics of growth has its counterpart in the political discussion. In particular, evidence has accumulated to suggest that traditional growth models do not tie up with stylized macroeconomic facts. In a model with exogenous saving rates, population growth and technological progress combined with diminishing returns to reproducible factors, there is no role for policy and richer countries grow at a slower rate than poorer countries adjusted for demographic differences. However, evidence of this process of convergence has weakened amongst the OECD countries in the most recent decades. Thus, the concept of convergence can only be reconciled with the data if one moves to conditional convergence, that is to say, the relation between growth rate and initial conditions after holding constant other variables. In particular, countries may persistently show differences in living standards and growth rates because of differences in saving rates, framework conditions and technological progress, all of which could be influenced by policy and institutions

The results have some implications for policy at the international coordination level. First, as countries develop and switch from imitative to innovative research and development, they are more likely to be interested in promoting stronger intellectual property protection. Second, it is important to understand that institutions are not created in a vacuum. Institutions, such as an intellectual property rights regime, are costly to create and maintain. Their emergence is likely to depend on whether the incentives are right - that is, whether the benefits outweigh the costs.

Current policy discussions often overlook this interdependence of intellectual property institutions and research. Less developed countries are expected to cooperate in providing stronger levels of property rights protection without regard to whether they have vested interests in creating the necessary institutions. A significant research base in those countries helps to generate incentives for providing property rights protection. Imitation therefore harms not just foreign inventors but also domestic inventors. Thus, the more advanced countries that have a vested interest in stronger global property rights should also find it in their interests to support the development of a research and development base in the lesser developed countries in exchange for support from the latter for an intellectual property infrastructure. Once such a base is established, research and development activities and property rights protection could grow in a complementary fashion.

\section{References}

Acemoğlu, D., James, A. R., and Simon, J. (2001). The Colonial Origins of Comparative Development: An Empirical Investigation. American Economic Review, 91, 1369-1401. Acemoğlu, D., Johnson, S. and Robinson, J. A. (2005). Institutions as a Fundamental Cause of Long-Run Growth. In: P. Aghion and S.N. Durlauf, eds., Handbook of Economic Growth, ed. Elsevier B.V., 385-472.

Alchian, A. and Demsetz, H. (1973). The Property Right Paradigm. Journal of Economic History, 33 (1), 16-27.

Andrés, R. and Goel, K. (2011). Corruption and Software Piracy: A Comparative Perspective. Policy \& Internet, 3, 1-22. 
Ata, A. Y. and Şahbaz, A. (2013). Mülkiyet Hakları ile Ekonomik Büyüme Arasındaki İlişki: AB Ülkeleri Üzerine Ampirik Bir İnceleme. Sosyoekonomi, 9(20), 161-180.

Bardsen, G. (1989). Estimation of Long Run Coefficients in Error Correction Models. Oxford Bulletin of Economics \& Statistics, 51(3), 345-350.

Barro, R. (1990). Government Spending in a Simple Model of Economic Growth. Journal of Political Economy, 98, 103-125.

Barzel, Y. (1997). Economic Analysis of Property Rights. Cambridge: Cambridge University Press.

Besley, T. and Ghatak, M. (2009). Property Rights and Economic Development. In: D. Rodrik and M. Rosenzweig, eds., Handbook of Development Economics, 1st ed. Elsevier, 4525-4595.

Boldrin, M. and Levine, D. (2009). Against Intellectual Monopoly, Cambridge University Press, Cambridge, UK.

Bose, N., Panini Murshid A., and Wurm, M. A. (2012). The Growth Effects of Property Rights: The Role of Finance. World Development, 40 (9), 1784-1797.

Branstetter, L., Fisman, R. and Foley, C. F. (2005). Do Stronger Intellectual Property Rights Increase International Technology Transfer? Empirical Evidence From U.S. Firm-Level Data. NBER Working Paper, No: 11516.

Cebula, R. J. (2011). Economic Growth, Ten Forms of Economic Freedom, and Political Stability: An Empirical Study Using Panel Data, 2003-2007. The Journal of Private Enterprise, 26(2), 61-81.

Cepeda, Cavazos, R., Lippoldt, D. and Senft, J. (2010). Policy Complements to the Strengthening of IPRs in Developing Countries. OECD Trade Policy Working Paper No. 104.

Chauffour, J. P. (2011). On the Relevance of Freedom and Entitlement in Development: New Empirical Evidence (1975-2007). World Bank Policy Research Working Paper:5660, World Bank, Washington, DC.

Chong, A., and Calderon, C. (2000). Institutional Quality And Income Distribution. Economic Development and Cultural Change, 48(4), 761-786.

Clague, C., Keefer, P., Knack, S. and Olson, M. (1999). Contract-intensive Money: Contract Enforcement, Property Rights and Economic Performance. Journal of Economic Growth, 4, 185-211.

Coase, R. (1998). The New Institutional Economics. The American Economic Review, 88(2), 72-74.

Dahlman, C. (1980). The Open Field System and Beyond. Cambridge: Cambridge University Press.

Demsetz, H. (1967). Toward a Theory of Property Rights. American Economic Review, 57, 61-70.

Dinçer, O. (2007). The Effects of Property Rights on Economic Performance. Applied Economics, 39, 825-837.

Easterly, W., and Levine, R. (2003). Tropics, Germs and Crops: How Endowments Influence Economic Development. Journal of Monetary Economics, 50(1), 3-39.

Eriçok, R. E. and Yılancı, V. (2013). Eğitim Harcamaları ve Ekonomik Büyüme İlişkisi: Sınır Testi Yaklaşımı. Bilgi Ekonomisi ve Yönetimi Dergisi, 8(1), 87-101. 
Everest, P., M. (2008). The Myth of Secure Property Rights: Good Economics as Bad History and its Impact on International Development. SPIRU Working Paper 23. London: Overseas Development Institute Working Paper.

Falvey, R., Foster, N. and Greenaway, D. (2006). Intellectual Property Rights and Economic Growth. Review of Development Economics, 10, 700-719.

Feder, G., and Feeny, D. (1991). Land Tenure and Property Rights: Theory and Implications for Development Policy. World Bank Economic Review, 5(1), 135-153.

Furubotn, E. G. and Pejovich, S. (1972). Property Rights and Economic Theory: A Survey of Recent Literature. Journal of Economic Literature, 10(4), 1137-1162.

Glaeser, E. L., La Porta, R., Lopez-de-Silane F., Shleifer, A. (2004). Do Institutions Cause Growth?. Journal of Economic Growth, 3(9), 271-303.

Goldsmith, A. (1995). Democracy, Property Rights and Economic Growth. Journal of Development Studies, 32(2), 157-174.

Gould, D. M. and Gruden, W. C. (1996). The Role Of Intellectual Property Rights In Economic Growth. Journal of Development Economics, 48, 323-350.

Granger, C. W. J. and Newbold, P. (1974). Spurious Regressions in Econometrics. Journal Of Econometrics, 2, 111-120.

Green, A. and Moser, C. (2012). Do Property Rights Institutions Matter at the Local Level? Evidence from Madagascar. Journal of Development Studies, 1-15.

Hayek, F. A. (1973). Law, Legislation and Liberty. Vol. 1: Rules and Order. London: Routledge and Kegan Paul.

Hudson, J. and Minea, A. (2013). Innovation, Intellectual Property Rights, and Economic Development: A Unified Empirical Investigation. World Development, 46, 66-78.

IPRI. (2014). International Property Rights Index Report 2014. Property Rights Alliance. Jacoby, Hanan G., Guo Li, and Scott Rozelle. (2002). Hazards of Expropriation: Tenure Insecurity and Investment in Rural China. American Economic Review, 92(5), 1420-1447. Johnson, S., McMillan, J. and Woodruff, C. (2002). Property Rights and Finance. NBER Working Paper, No:8852.

Johansen, S. and Juselius, K. (1990). Maximum Likelihood Estimation and Inference on Cointegration With Applications to The Demand for Money. Oxford Bulletin OfEconomics and Statistics, 52, 169-210.

Kamas, L., and Joyce, J. P. (1993). Money, Income and Prices under Fixed Exchange Rates: Evidence from Causality Tests and VARs. Journal of Macroeconomics, 15(4), 747-768. Kanwar, S. and Evenson, R., (2003). Does Intellectual Property Protection Spur Technological Change?. Oxford Economic Papers, 55, 5-264.

Keefer, P. (2007). Governance And Economic Growth, quoted in Winters, L. Alan and Shahid Yusuf, Dancing with Giants, Washington DC., World Bank.

Keefer, P. and Knack, S. (2002). Polarization, Politics And Property Rights: Links Between Inequality And Growth. Public Choice, 111, 127-154.

Kerekes, C. B. and Williamson, C. R. (2008). Unveiling De Soto's Mystery: Property Rights, Capital Formation, and Development. Journal of Institutional Economics, 4(33), 299-325. 
Khan, Z. B. (1995). Property Rights and Patent Litigation in Early Nineteenth- Century America. The Journal of Economic History, 55(1), 58-97.

Knack, S. and Keefer, P. (1995). Institutions and Economic Performance: Cross-Country Tests using Alternative Measures. Economics and Politics, 7, 207-220.

La Porta, R., Lopez, F., and Shleifer, A. (2008). The economic consequences of legal origins. Journal of Economic Literature, 4(2), 285-332.

Leblang, D. A. (1996). Property Rights, Democracy and Economic Growth. Political Research Quarterly, 49(1), 5-26.

Lerner, J. (2009). The Empirical Impact of Intellectual Property Rights on Innovation: Puzzles and Clues. American Economic Review, 99, 343-348.

Libecap, G. (1989). Contracting for Property Rights. Cambridge University Press. Cambridge.

Lipset, S. M. (1960). Political Man: The Social Bases of Politics. New York: Doubleday. Mahoney, J. T. (2004). Economic Foundation of Strategy, Sage Publication.

McLennan, P. and Le, Q. (2011). The Effects Of Intellectual Property Rights Violations On Economic Growth. Modern Economy, 2, 107-113.

Mijiyawa, A. (2009). Democracy Rules: The Prevalence of Political Approach in Determining the Quality of Private Property Rights Institutions. Working Paper, 1-44.

Mocan, N. (2004). What Determines Corruption? International Evidence From Micro Data. NBER Working Paper Series, No. 10460.

Montesquieu. (1748). The spirit of laws. With the exception of the chapter on commerce, which is not in the Carrithers edition, all page number citations are from Montesquieu (ed. Carrithers 1977). The chapter on commerce is taken from the complete version of Spirit at http://www.constitution.org/cm/sol-02.htm, accessed on 4 April 2015.

Narayan, P. K. (2005). The Saving And Investment Nexus for China: Evidence From Cointegration Tests. Applied Economics, 37(17), 1979-1990.

Narayan, P. K. and Narayan, S. (2005). Estimating Income and Price Elasticities of Imports For Fiji in a Cointegration Framework. Economic Modelling, 22, 423-438.

Narayan, P. K. and Smyth, R. (2005). Trade Liberalization and Economic Growth in Fiji An Empirical Assessment Using the ARDL Approach. Journal of The Asia Pacific Economy, 10(1), 96-115.

Narayan, P. K. and Smyth, R. (2006). What Determines Migration Flows From LowIncome to High-Income Countries? An Empirical Investigation of Fiji-U.S. Migration 1972-2001. Contemporary Economic Policy, 24(2), 332-342.

Nee, V. (2003). The New Institutionalism in Economics and Sociology. CSES Working Paper Series, 4, November.

North, D. and Weingast, B. (1989). Constitutions and Commitment: The Evolution of Institutions Governing Public Choice in Seventeenth-Century Britain. Journal of Economic History, 49(4), 803-832.

North, D. (1990). Institutions, Institutional Change and Economic Performance. Cambridge: Cambridge University Press.

North, D. C. (1991). Institutions. The Journal of Economic Perspectives, 5(1), 97-112. 
North, D. C. (2002). Kurumlar, Kurumsal Değişim ve Ekonomik Performans. Çev: Gül Çağalı Güven, Cambridge University Press, Sabancı Üniversitesi Yayınları, İstanbul.

Ojah, K., Gwatidzo, T. and Kaniki, S. (2010). Legal Environment, Finance Channels and Investment: The East African Example. The Journal of Development Studies, 46(4), 724-744.

Park, G. and Ginarte, J. (1997). Intellectual Property Rights And Economic Growth. Contemporary Economic Policy, 15, 51-61.

Pesaran, M. H. (1997). The Role of Economic Theory in Modeling The Long Run. The Economic Journal, 107(440), 178-191.

Pesaran, M. H., Shin, Y. and Smith, R. J. (2001). Bounds Testing Approaches to The Analysis of Level Relationships. Journal of Applied Econometrics, 16, 289-326.

Pourshahabi, F. Mahmoudinia, D. and Soderjani, E. S. (2011). FDI, Human Capital, Economic Freedom and Growth in OECD Countries. Research Journal of International Studies, 19, 71-81.

Przeworski, A. and Fernando, L. (1993). Political Regimes and Economic Growth. Journal of Economic Perspectives, 7(3), 51-69.

Rodrik, D. (2000). Institutions For High-Quality Growth: What They Are And How To Acquire Them. NBER Working paper 7540.

Rodrik, D. (2004). Getting Institutions Right. CESIFO DICE Report, 2(2), 10-15.

Richardson, C. J. (2005). The Loss of Property Rights and The Collapse of Zimbabwe. Cato Journal, 25(3), 541-565.

Samuel, A. (2011). Intellectual Property Rights, Innovations, And Economic Growth In Sub-Saharan Africa. Journal of Third World Studies, 28, 231-236.

Sattar, A. and Mahmood, T. (2011). Intellectual Property Rights And Economic Growth: Evidences From High, Middle And Low Income Countries. Pakistan Economic and Social Review, 49, 163-186.

Smith, A. (1776). An Enquiry into the Nature and Causes of the Wealth of Nations, Ed. Svensson, J. (1998). Investment, property rights and political instability: Theory and evidence. European Economic Review, 42(7), 1317-1341.

Şimşek, M. and Kadılar, C. (2005). Türkiye'nin İhracat Talebi Fonksiyonunun Sınır Testi Yöntemi ile Eşbütünleşme Analizi. Doğuş Üniversitesi Dergisi, 6(1), 144-152.

Tarı, R. and Yıldırım, D. Ç. (2009). Döviz Kuru Belirsizliğinin İhracata Etkisi: Türkiye İçin Bir Uygulama. Yönetim ve Ekonomi Dergisi, 16(2), 95-105.

Thompson, M. and Rushing, F. (1999). An Empirical Analysis Of The Impact Of Patent Protection Of Economic Growth: An Extension. Journal of Economic Development, 24, 67-76.

Tornell, A. (1997). Economic Growth and Decline With Endogenous Property Rights. Journal of Economic Growth, 2, 219-250.

Torstensson, J. (1994). Property Rights and Economic Growth: An Empirical Study. Kyklos, 47, 231-247.

Uzun, M. (2009). Mülkiyet Hakları ve Ekonomik Gelişme. Cumhuriyet Üniversitesi İktisadi ve İdari Bilimler Dergisi, 23(1), 291-308. 
Valeriani, E. and Peluso, S. (2011). The Impact Of Institutional Quality On Economic Growth And Development: An Empirical Study. Journal of Knowledge Management, Economics and Information Technology, 1(6), 1-25.

Yapraklı, S. (2010). Türkiye'de Esnek Döviz Kuru Rejimi Altında Dış Açıkların Belirleyicileri: Sınır Testi Yaklaşımı. Ankara Üniversitesi SBF Dergisi, 65(4), 141-164.

Yılancı, V. (2009). Fisher Hipotezinin Türkiye İçin Sınanması: Doğrusal Olmayan Eşbütünleşme Analizi Yaklaşımı. Atatürk Üniversitesi İktisadi ve İdari Bilimler Dergisi, 23(4), 205-213.

Yılancı, V. (2012). Türkiye'de Para Talebi İstikrarlılığının Testi: Kayan Pencerelerde Sınır Testi Yaklaşımı. Dumlupınar Üniversitesi Sosyal Bilimler Dergisi, 33, 67-74.

Williamson, O. E. (1985). The Economic Institutions of Capitalism. New York: The Free Press. 